\title{
Estudo das imagens radiológicas nas complicações do transplante alogênico de medula óssea
}

\section{Imaging study in clinical complications of allogenic bone marrow transplantation}

Jenner Lazzaro

Orientador: Frederico Luiz Dulley

\section{Resumo}

Objetivos: Demonstrar a utilidade dos métodos radiológicos, a saber: radiografia convencional e contrastada, tomografia computadorizada convencional e tomografia computadorizada de alta resolução e ressonância nuclear magnética no diagnóstico das complicações do transplante alogênico de medula óssea, principalmente a doença enxerto contra o hospedeiro e infecções oportunistas, reduzindo a necessidade de procedimentos invasivos que coloquem em risco os pacientes.

Casuística e Métodos: Os exames radiológicos de vinte pacientes foram analisados retrospectivamente no período de 1991 a 2002. Os métodos utilizados foram: radiografia simples convencional e contrastada, tomografia convencional e de alta resolução, e ressonância nuclear magnética.

Setenta e cinco por cento dos pacientes eram do sexo masculino e 25\% do sexo feminino. A média de idade foi de 33,4 anos com variação de 16 a 55 anos; as doenças diagnosticadas ao transplante foram respectivamente: LMC em 50\% dos pacientes, $25 \%$ aplasia de medula, 15\% LMA, 5\% DH e 5\% SMD.

Resultados: Dos vinte pacientes estudados; um foi submetido à radiografia simples do tórax, um à radiografia simples dos seios da face, dois à radiografia contrastada de alças delgadas (trânsito intestinal), dois à tomografia computadorizada dos seios da face, um à tomografia computadorizada do crânio, um à tomografia computadorizada convencional do tórax, nove à tomografia de alta resolução do tórax, três à tomografia computadorizada do abdômen e dois à ressonância magnética nuclear do crânio.

Em 90\% dos pacientes foi necessário apenas um exame radiológico para detectar anormalidade e em apenas dois pacientes (10\%) foi necessário um exame radiológico adicional para confirmação ou esclarecimento da alteração.

Observou-se em primeiro lugar com sete casos: infecção pulmonar por citomegalovírus, em segundo com três casos de cada complicação: infecção pulmonar por aspergillus, doença enxertocontra o hospedeiro pulmonar de diagnóstico apenas radiológico e doença enxerto-contra o hospedeiro pulmonar confirmada com biópsia.

Em terceiro lugar com dois casos de cada complicação: sinusite por aspergillus, infecção pulmonar por pneumocistis carinii e doença enxerto-contra o hospedeiro intestinal. Em quarto lugar com um episódio de cada complicação: colite por citomegalovírus, colite neutropênica inespecífica, pneumonia bacteriana, infecção pulmonar por tuberculose, doença veno-oclusiva hepática, sinusite inespecífica, neurotoxoplasmose, neurocisticercose, hepatite por vírus $\mathrm{B}$, pancreatite e sepsis complicada por acidente vascular cerebral hemorrágico.

Conclusão: A relação dos achados radiológicos com o tempo transcorrido desde o transplante alogênico de medula óssea é de grande auxílio para estabelecer o diagnóstico principalmente da doença enxerto-contra o hospedeiro e das complicações pulmonares. Os métodos radiológicos foram de capital importância para a instituição da terapêutica clínica, sendo que, em parte dos casos, evitouse o procedimento invasivo antecedendo assim o resultado dos exames laboratoriais que podem não ser de resultado imediato.

\section{Abstract}

Purpose: To demonstrate the utility of radiological methods in the diagnoses of complications of allogenic bone marrow transplantation, especially pulmonary and opportunistic infections, thereby diminishing the need for invasive procedures that might be hazardous to patients.

Patients and Methods: The radiological exams of 20 patients were analyzed retrospectively during the period of 1991 to 2002. The following methods were employed: plain conventional and contrast enhanced radiography, conventional and high resolution tomography and magnetic resonance imaging.

A total of $75 \%$ of patients were male and $25 \%$ female. Average age was 33.4 years (range 16 to 55 years); the diseases diagnosed at the time of transplantation were: chronic myelogenous leukemia in $50 \%$ of patients, aplastic anemia in $25 \%$, acute myelogenous leukemia in $15 \%$, Hodgkin's disease in $5 \%$, and myleodysplasic syndrome in $5 \%$.

Results: Of the twenty patients studied, one was submitted to plain chest radiography, one to plain radiography of facial sinuses,

Tese de dissertação para obtenção de grau de Mestre em Clínica Médica da Faculdade de Medicina da Universidade de São Paulo.

Correspondência: Jenner Lazzaro

Rua Sena Madureira, 1.265 apto 91 - Vila Clementina

04021-051 - São Paulo-SP - Brasil

E-mail: jenner2@terra.com.br 
two to small bowel contrast enhanced plain radiography, two to conventional computed tomography of the facial sinus, one to conventional computed tomography of the brain, one to conventional computed tomography of the chest, nine to high resolution chest tomography, three to conventional abdominal computed tomography and two to brain magnetic resonance imaging.

In $90 \%$ of patients one radiological examination was enough to demonstrate the abnormal findings whilst in only two patients (10\%) more than one imaging examination was necessary in order to confirm or clarify the abnormal findings.

The findings observed in decreasing order of frequency were: 7 cases of pulmonary infection by cytomegalovirus followed by 3 cases each of the following complications: pulmonary infection by aspergillus, pulmonary graft-versus-host disease diagnosed only by radiological findings and pulmonary graft-versus-host disease confirmed by biopsy.

The third most frequent complication observed with two cases each were: sinusitis by aspergillus, pulmonary infection by pneumocistis carinii and intestinal graft-versus-host disease. Fourth in frequency with one case for each complication were: cytomegalovirus colitis, unspecific neutropenic colitis, bacterial pneumonia, pulmonary tuberculosis, hepatic veno-occlusive disease, unspecific sinusitis, neurotoxoplasmosis, neurocysticercosis, B viral hepatitis, pancreatitis and sepsis complicated by cerebral hemorrhagic stroke.

Conclusion: the relationship between radiological findings and the time elapsed since allogenic bone marrow transplantation is of great help to clarify the diagnosis, especially of graft-versus-host disease and pulmonary complications. The imaging methods were of great importance for initiating adequate therapeutic measures and for also avoiding in some cases invasive diagnostic procedures; earlier than the results of laboratorial examinations that may not be immediately available.

Avaliação:

A Revista Brasileira de Hematologia e Hemoterapia publica os resumos e abstracts de teses da área apresentados em entidades que tenham programas de pós-graduação reconhecidos pelo MEC/Capes e considera a obtenção do título suficiente para sua publicação na forma como se propõe a seção.

Recebido: 28/07/2006

Aceito: 31/07/2006 